\title{
KAZAKISTAN CUMHURIYETI: TÜRK DEVLETLERI TEŞKILATI'NIN ÖNCÜ ÜLKESi
}

\section{Teoman Ertuğrul TULUN}

\section{Analist}

Türk Dili Konuşan Ülkeler İşbirliği Konseyi (Türk Konseyi), 3 Ekim 2009'da Nahçıvan'da Türk Devletleri arasında kapsamlı işbirliğini teşvik etmek amacıyla uluslararası bir örgüt olarak kurulmuştur. Türk dünyasının yol gösterici bir değeri olarak gelişen bu teşkilatın kurucu üyeleri arasında Kazakistan Cumhuriyeti de yer almaktadır.[1] Bu bağlamda, Kazakistan Cumhuriyeti'nin kurucusu ve ilk Cumhurbaşkanı Nursultan Nazarbayevin Türk Konseyi fikrini ilk olarak gündeme getiren ve Konseyin bir teşkilat olarak uluslararası platforma taşınmasına yardımcı olan vizyoner bir devlet adamı olduğunun belirtilmesi gerekir. Bu bağlamda, Cumhurbaşkanı Nazarbayev'in liderliğinde Kazakistan'ın, işbirliğini geliştirmek için bir başka değerli hükümetlerarası forum olan ve Asya'da barışı, güvenliği ve istikrarı teşvik etmek için oluşturulan Asya'da İşbirliği ve Güven Artırıcı Önlemler Konferansı'nın (CICA/AIGK)) kurucusu ve fikir babası olduğunu belirtmekte de yarar bulunmaktadır.

Türk Devletleri Teşkilatı'nın kurucu üyeleri Azerbaycan, Kazakistan, Kırgızistan ve Türkiye'dir. Ekim 2019'da Bakü'de düzenlenen 7. Zirve'de Özbekistan, Örgüte tam üye olarak katılmıştır. Eylül 2018'de Kırgızistan'ın Çolpon-Ata (Çolpan-Ata) kentinde düzenlenen 6. Zirve'de Macaristan, Kasım 2021'de İstanbul'da düzenlenen 8. Zirve'de ise Türkmenistan Teşkilata gözlemci statüsü ile katılmıştır.

Teşkilatın temel belgeleri olan 3 Ekim 2009 tarihli Nahçıvan Anlaşması ve 16 Eylül 2010 tarihli İstanbul Bildirisi'ne göre, Teşkilata üye ülkeler, Birleşmiş Milletler Anlaşması'nın amaçları ve ilkelerinin yanı sıra uluslararası hukukun diğer evrensel olarak tanınan ilkelerini benimsemiştir. Barış ve güvenliğin korunması ile iyi komşuluk ilişkilerinin geliştirilmesine ilişkin uluslararası normlar, Türk Konseyi çatısı altında yürütülecek işbirliğinin zeminini oluşturmaktadır.

Nahçıvan Anlaşmanın önsözünde üye devletler, Birleşmiş Milletler Anlaşması'nın amaç ve 
ilkelerine bağlılıklarını teyit ederek, Teşkilatın temel amacını, Türk Devletleri arasında kapsamlı işbirliğini derinleştirmek, bölgesel ve küresel barış ile istikrara katkıda bulunmak olarak tanımlamıştır. Üye ülkeler ayrıca, demokrasi, insan haklarına saygı, hukukun üstünlüğü ve iyi yönetişim gibi temel ilkelere bağlılıklarını ifade etmiştir. Teşkilat kapsamındaki işbirliği, üye ülkeler arasındaki ortak tarih, kültür, kimlik ve Türk dili konuşan halkların dil birliğinden kaynaklanan özel dayanışma temelinde inşa edilmektedir.

Örgütün, Nahçıvan Antlaşması'nın 2. maddesinde belirtilen, temel amaç ve görevleri şu şekildedir:

- Taraflar arasında karşılıklı güvenin güçlendirilmesi;

- Bölge ve bölge dışında barışın korunması;

- Dış politika konularında ortak tutumlar benimsenmesi;

- Uluslararası terörizm, ayrılıkçılık, aşırılık ve sınır ötesi suçlarla mücadele için eylemlerin koordine edilmesi;

- Ortak amaçlarla ilgili her alanda etkili bölgesel ve ikili işbirliğinin geliştirilmesi;

- Ticaret ve yatırım için uygun koşulların yaratılması;

- Kapsamlı ve dengeli bir ekonomik büyüme, sosyal ve kültürel gelişimin amaçlanması;

- Hukukun üstünlüğünün sağlanması, iyi yönetişim ve insan haklarının korunması konularının tartışılması;

- Bilim, teknoloji, eğitim ve kültür alanlarında etkileşimin genişletilmesi;

- Kitle iletişim araçlarıyla etkileşimin ve daha yoğun bir iletişimin teşvik edilmesi;

- Hukuki konularda bilgi değişimi ve adli işbirliğinin teşvik edilmesi.

Türk Devletleri Teşkilatı, Kasım 2021'de Türk Konseyi'nin İstanbul'daki 8. Zirvesi'nde kurulmuştur. Türk Dili Konuşan Ülkeler İşbirliği Konseyi'nin (Türk Konseyi) ismi, Türk Devletleri Teşkilatı olarak değiştirilmiştir. Bu bağlamda Türk Devletleri Teşkilatı'nın, 1992 yılından bu yana düzenlenen "Türkçe Konuşan Ülkeler Devlet Başkanları Zirveleri"nin doruk noktasını oluşturduğunu söylemek mümkündür. Bu süreçte, on zirve toplantısı yapılmıştır. 16 Eylül 2010 tarihinde İstanbul'da yapılan Zirve'de Türk Konseyi'nin kuruluşu resmen duyurulmuş, öncelikleri ve yol haritası belirlenmiş ve Teşkilat'ın daimi yapısı ilan edilmiştir. Ayrıca zirvelerin adı da Türk Devletleri Zirveleri olarak değiştirilmiştir. Yukarıda da belirttiğimiz gibi bu değerli platform, 2021 yılında İstanbul'da tam teşekküllü uluslararası bir teşkilata dönüşmüştür.

Yukarıdaki açıklamalardan da anlaşılacağı üzere Kazakistan, Türk Devletleri Teşkilatı'nın seçkin bir üyesidir. Kazakistan'ın istikrar ve barışı, sadece Orta Asya bağlamında değil, Türk dünyası için de güvenlik ve istikrar açısından büyük önem taşımaktadır. Bu kapsamda Kazakistan'da çalkantılara neden olan gelişmeler Türk Devletleri Teşkilatı tarafından yakından takip edilmektedir. AViM olarak, Kazakistan halkının sağduyusuna olan güvenimiz tamdır. Önümüzdeki günlerin Kazakistana barış, huzur ve istikrar 
getirmesini diliyoruz.

*Fotoğraf: https://tr. wikipedia.org/

**Bu Yorum yazısının aslı ingilizce olarak kaleme alınmıştır.

[1] Takip eden açıklamada Türk Konseyi'nin "fikir babasının Cumhurbaşkanı Nazarbayev"'" olduğuna atıfta bulunulmaktadır. Statement on Granting the First President of the Republic of Kazakhstan-Elbasy, H.E Nursultan Nazarbayev, the Status of the Life-Time Honorary President of the Turkic Council (Organization of Turkic States, 24 Mayıs 2019), https://www.turkkon.org/en/haberler/statement-on-granting-the-first-president-of-therepublic-of-kazakhstan-elbasy-he-nursultan-nazarbayev-the-status-of-the-life-timehonorary-president-of-the-turkic-council_1830.

Yazar Hakkında :

Teoman Ertuğrul Tulun , Avrasya İncelemeleri Merkezi'nde (Ankara) analisttir. Bilkent Üniversitesi'nde Siyaset Bilimi ve Kamu Yönetimi Bölümünde doktora adayıdır. Avrupa Birliği Çalışmaları, Toplumsal Hareketler, Irkçılık ve Nefret Söylemi Çalışmaları ve Devlet Inşaası alanlarında çalışmalar yapmaktadır.

Atıfta bulunmak için: TULUN, Teoman Ertuğrul. 2022. "KAZAKISTAN CUMHURIYETi: TÜRK DEVLETLERi TEŞKILATI'NIN ÖNCÜ ÜLKESi." Avrasya Incelemeleri Merkezi (AVIM), Yorum No.2022 / 3. Ocak 07. Erişim Ocak 07, 2022. https://avim.org.tr/tr/Yorum/KAZAKISTAN-CUMHURIYETI-TURK-DEVLETLERITESKILATI-NIN-ONCU-ULKESI

\section{(2) AVIM}

Süleyman Nazif Sok. No: 12/B Daire 3-4 06550 Çankaya-ANKARA / TÜRKIYE

Tel: +90 (312) 43850 23-24 • Fax: +90 (312) 4385026

@avimorgtr

I https://www.facebook.com/avrasyaincelemelerimerkezi

E-Posta: info@avim.org.tr

http://avim.org.tr

(C) 2009-2021 Avrasya incelemeleri Merkezi (AViM) Tüm Hakları Saklıdır 